\title{
Determination and Remediation of Selected Polycyclic Aromatic Hydrocarbons in Petroleum Contaminated Water
}

\author{
${ }^{* 1}$ IJAOLA, OO; ${ }^{2}$ SANGODOYIN, AY \\ ${ }^{*}$ Department of Civil Engineering, Faculty of Engineering, Federal University Otuoke, Bayesla state, Nigeria. \\ ${ }^{2}$ Department of Agricultural and Environmental Engineering, Faculty of Technology, University of Ibadan, Ibadan Nigeria. \\ *Corresponding Author Email: opodengineer@yahoo.com, oladimarunengineer@gmail.com
}

\begin{abstract}
Determination and remediation of pollutants such as polycyclic aromatic hydrocarbons (PAHs) have not being fully regulated in Nigeria; hence contamination of surface water by such pollutant is a major concern. This study was designed to determine the level of selected PAHs in petroleum contaminated water using spectroscopic techniques and the efficacy of activated carbons made from Bambusa vulgaris and Oxytenanthera vabyssinaca. Bambusa vulgaris and Oxytenanthera abyssinaca were carbonized at $350^{\circ} \mathrm{C}$ and activated with Phosphoric acid $\left(\mathrm{CBV} 350^{\circ} \mathrm{C}_{3} \mathrm{PO}_{4}\right)$ and Potassium chloride $\left(\mathrm{COA} 350^{\circ} \mathrm{C} \mathrm{KCl}\right)$ as dehydrating agent respectively. The adsorbents were then used to remediate PAHs in petroleum contaminated water. Liquid-Liquid extraction procedures were used for extracting selected PAHs from sampled solutions. The batch experiment was performed to study the adsorption capacity of adsorbents at $5 \mathrm{hrs}$ contact time. Analysis of PAHs concentration for each sampling day was determined by GC-MS. Total PAHs in simulated wastewater did not show a clear trend, contrary to the expectation that there should be a progressive increase with time due to photolysis or photodecomposition of compounds or PAHs. $\mathrm{COA} 350^{\circ} \mathrm{C} \mathrm{KCl}$ showed a range of 6.2-19.3\% removal efficiency of each selected PAH with a total percentage efficiency of 27.7-70.8 for all days. For $\mathrm{CBV} 350^{\circ} \mathrm{C} \mathrm{H}_{3} \mathrm{PO}_{4}$ removal efficiency ranged from $10.26-19.30 \%$ for each selected $\mathrm{PAH}$ and a total efficiency of $50.8-100 \%$ for all selected PAHs for the 4 days intervals. The experimental result showed that adsorbent made from Bambusa vulgaris and Oxytenanthera abyssinaca and activated with $\mathrm{H}_{3} \mathrm{PO}_{4}$ and $\mathrm{KCl}$ as dehydrating agent respectively can efficiently adsorb the selected PAHs in contaminated water. The study also revealed that PAHs in contaminated water increases with time due to photodecomposition, thus necessitating their treatment on time.
\end{abstract}

DOI: $\underline{\text { https://dx.doi.org/10.4314/jasem.v24i3.10 }}$

Copyright: Copyright $(\subset) 2020$ Ijaola and Sangodoyin. This is an open access article distributed under the Creative Commons Attribution License (CCL), which permits unrestricted use, distribution, and reproduction in any medium, provided the original work is properly cited.

Dates: Received: 16 November 2019; Revised: 11 January 2020; Accepted: 22 February 2020

Keywords: Polycyclic Aromatic Hydrocarbons, Adsorbents, Remediate, Petroleum contaminated water

Contamination of waterways and groundwater by petroleum substances has been a major issue of concern in the Niger Delta areas of Nigeria. The petroleum industry is a major life-wire of Nigeria's income and economic growth. According to reports, its operation started way back in 1958, and since then many researches have been conducted on the production of petroleum products, the causes and effects of petroleum pollution on the Nigerian environment (Ekundayo and Obuekwe, 1997; Ayotamuno et al., 2002; Aroh et al., 2010; Isehunwa and Onovae, 2011; Kadafa, 2012). Produced water and crude oil spills are the major sources of pollutants generated by the petroleum industry. Produced water is the largest by-product or wastewater attributed to the petroleum industry and consists of salt, organic and inorganic compounds. At times crude oil spills can be attributed to equipment failure during operation or damages that arise from production facilities by vandals (Kadafa, 2012). The attribute of water polluted with crude oil and that of produced water are similar because of their hydrocarbon content.
Among the organic constituent of crude oil is a group of hydrocarbons called polycyclic aromatic hydrocarbons, PAHs (Pampanine and Sydnes, 2013). These are large group of organic contaminants, which are characterized by the presence of at least two fused aromatic rings and are seen by the United State Environmental Agency (USEPA) as priority organic pollutants (USEP, 1994). Fluorene, Phenanthrene, Anthracences, Benz (e) acephenanthrylene and Benzo(e)pyrene are some of the prior PAHs contained in Nigeria petroleum. PAHs are highly lipophilic contaminants which are ubiquitously present in the environment (WHO, 1998). Because of their low biodegradation and bioaccumulation in the adipose tissues of organisms and biomagnifications through the food chain, they are considered as persistent organic pollutants, POPs (Haritash and Kaushik, 2009).

Most of the organic contaminants in water and wastewater associated with the petroleum industries are known to have adverse effect on surface waters, 
which in some case is source of livelihood. The rapid decrease in the level of water resources and increasing demand of water for consumption in our daily life has necessitated determination and remediation pollutants in industrial wastewater before disposal (Sangodoyin, 1993). Modern instrumental techniques developed for environmental concern are chromatographic separation and spectroscopic methods such as gas and liquid chromatography (GC and LC). These separating techniques are useful for identification and quantification of organic contaminants, metabolites and transformation products like PAHs (Noelia, 2011; Lindholm- Lehto et al, 2016). These pollutants cause severe environmental, ecological, and economic consequences in oil spill environments, hence the need effective decision to prevent the long-term effect impact on such geographical isolated locations (Raymond, et al; 2017: Arockiara, et al; 2019) Most of the oil and gas industries in the Delta region make use of conventional treatment methods such as the Induced Gas Flotation (IGF) or the Induced Air Flotation known as WEMCO and Enviro-cell. These are considered not adequate for remediation of dissolved hydrocarbons. Dissolved hydrocarbon in petroleum wastewater can best be removed by other fundamental mechanisms like absorption, adsorption, extraction, membrane filtration or oxidation (John et al, 2004; Jeffrey 2010). Meijer and Madin (2010) showed that techniques based on adsorption, like activated carbon or polymeric micro porous sorbents with big internal surfaces are certainly able to remove dissolved hydrocarbons. To ensure compliance with future discharge requirements, new technologies with granular activated carbon is envisaged as the next step in improvement of Petroleum wastewater treatment (Meijer and Madin, 2010). This study seek to determine the level of selected PAHs in petroleum contaminated water using spectroscopic technique and also examine the efficacy of carbonized Bambusa vulgaris and Oxytenanthera abyssinaca as adsorbents.

\section{MATERIALS AND METHODS}

Bambusa vulgaris and Oxytenanthera abyssinaca were carbonized at $350^{\circ} \mathrm{C}$ and activated with Phosphoric acid $\left(\mathrm{H}_{3} \mathrm{PO}_{4}\right)$ and Potassium chloride $(\mathrm{KCl})$ as dehydrating agent respectively. These adsorbents were then used to remediate PAHs in petroleum contaminated water.

Formation of Petroleum contaminated water: In order to identify the quantity of Polycyclic Aromatic Hydrocarbon (PAHs) in petroleum wastewater as well as remediating it with produced adsorbent, crude oil sample was collected from petroleum industry in Nigeria. Adsorption behavior of PAHs in petroleum wastewater onto bamboo activated carbon was investigated by simulating petroleum wastewater with $2.5 \mathrm{~L}$ of Bonny light crude oil and distilled water of $50 \mathrm{~L}$ containing $3.5 \% \mathrm{NaCl}$ salt. $\mathrm{NaCl}$ salt was used in the simulation in order to create an artificial aquatic environment according to Zubaidy, (2012). The simulated petroleum wastewater was then left to weather for $48 \mathrm{hrs}$. Sampling of simulated produced water was done within 4days at daily intervals. Analysis of PAHs concentration for each sampling day was determined by GC-MS. This was done in order to monitor the change in PAHs concentration as a result of change in days.

Adsorption Experiment: All experiments were carried out at ambient temperature. The batch experiment was performed to study the adsorption capacity of adsorbents. $200 \mathrm{ml}$ of simulated petroleum wastewater was sampled into different conical flasks of $250 \mathrm{ml}$ capacity. One gramme of $B$. vulgaris adsorbent and $O$. abyssinaca adsorbent was weighed into the conical flasks to form an adsorbent/solute solution. Solutions were agitated at a stirring speed of $160 \mathrm{rpm}$ to ensure intimate contact of the adsorbent and solute in solution, while observing each solution in equilibrium for $5 \mathrm{hrs}$ contact time to attain dynamic equilibrium. After 5 hrs., solutions were filtered with $0.45 \mu \mathrm{m}$ paper and the filtrate of $150 \mathrm{ml}$ were poured into amber bottles with Teflon cap and kept at temperature of $4^{\circ} \mathrm{C}$ for further analysis of extraction, clean up and GCMS. The 5 hrs contact time was chosen based on the experiment performed at the terminal station of the oil and gas industry. For accuracy, all experimental analysis was duplicated. The amount of selected PAHs $\left(q_{e}\right)$ adsorbed by $B$. vulgaris adsorbent and $O$. abyssinaca adsorbent can be expressed mathematically as:

$$
\mathrm{q}_{\mathrm{e}}=\frac{\mathrm{C}_{\mathrm{o}}-\mathrm{C}_{\mathrm{e}}}{\mathrm{M}} \times \mathrm{v} \quad \ldots \ldots \ldots \ldots \ldots \ldots \ldots \ldots \ldots \ldots
$$

The percentage removal is evaluated using

$$
\% \text { Removal }=\frac{\mathrm{C}_{\mathrm{o}}-\mathrm{C}_{\mathrm{e}}}{\mathrm{C}_{\mathrm{o}}} \times 100 \ldots .2
$$

Where: $\mathrm{V}$ is the volume of PAHs in solution (L); Co is initial concentrations of PAHs (mg/l); $\mathrm{Ce}$ is equilibrium concentrations of PAHs (mg/l); $\mathrm{M}$ is the mass of the adsorbent $(\mathrm{g})$.

Solvents and Chemicals used: All solvents and chemicals used are of analytical grade with $99.0 \%$ purity. A standard mixture of 16 priority PAHs of 2.0 $\mathrm{mg} / \mathrm{ml}$ each was used to calibrate the GC-MS used for selected PAHs analysis. Dichloromethane and nHexane made by Loba(LO)chemice (India), Silica gel of 60-200 mesh size 500g for chromatography made 
by Oxford laboratory(India) and Sodium Sulphate Anhydrous of $500 \mathrm{~g}$ made by Qualikems (India) where all purchased from Labio Scientific Centre in Nigeria.

Extraction technique: Liquid-Liquid extraction procedures were used for extracting selected PAHs from sampled solutions. Mixture of dichloromethane (DCM) and n-Hexane in ratio 3:1 was used as extractant. The extraction processes were repeated twice for each sample. Cleanup of selected PAHs was carried out with $1 \mathrm{~cm}$ of moderate packed cotton wool placed at the bottom of each $10 \mathrm{~mm}$ ID $250 \mathrm{~mm}$ loup chromatographic column used. Two grammes of activated silica gel and 10ml of 3:1 (DCM and hexane) was prepared and placed in the chromatographic column. To the top of the column was added $0.8 \mathrm{~cm}$ of anhydrous sodium sulphate. The column was rinsed with additional $20 \mathrm{ml}$ mixture of 3:1 (DCM and Hexane) to pre-elute the column. Elute was allowed to flow though the column for about $2 \mathrm{~min}$ or until the liquid in the column was just above the sulphate layer. Thereafter, $3 \mathrm{ml}$ of extracted samples was transferred into each prepared column. The extraction bottles were rinsed with $1 \mathrm{ml}$ of DCM (3) and Hexane (1)/eluent and added to the column as well. The stop cork of the column was opened and the aromatic extract collected into $10 \mathrm{ml}$ graduated cylinder each was allowed to concentrate and evaporate under oxygenated conditions and later kept at $4^{0} \mathrm{C}$ before GC-MS analysis.

Determination of Selected PAHs in petroleum contaminated water by GC-MS: Quantification of PAHs was by an external standard method which relies on the reproducibility of the standard preparation. The linearity of external calibration was done by preparing different concentration of PAHs mix standards at dilution rate of $12.5,25,50,100$ and 200ppm according to the specification given by the International Conference for Harmonization that requires a 5 point calibration curve serial dilution. The linearity was evaluated at different concentration using response factors and all showed good linearity with regression coefficients ranging from 0.972 to 1.000 for all PAHs. USEPA method 8270 was employed in GC-MS analysis. The gas chromatography that was used was Agilent Technologies 7890-A GC system G-3440-A A.01.14 series, coupled with Mass spectrometry detector (MS) Agilent Technologies 5975-C VL MS D series with Agilent Technologies 7683-B series injector powered with MSD chem-station G1701-EA E.02.10.1177 software to identify and quantify analytes in compounds. Selected hydrocarbon compounds were identified on the basis of their retention time and by comparing them to those of analytical standards. Matrix spikes, duplicates, solvent, and method blanks were also analyzed as quality control samples.

\section{RESULTS AND DISCUSSION}

Table 1 shows the physical properties of the crude oil sample that was simulated. The concentration of PAHs in the simulated petroleum wastewater on daily basis for 4 days and the initial concentration of PAHs in crude oil sample are detailed in Table 2.

\begin{tabular}{ll}
\multicolumn{2}{l}{ Table 1 Characteristic of investigated crude oil sample } \\
\hline Physical Properties & Crude Oil \\
\hline Appearance & Dark Brown \\
Water Content ( $\%$ zol) & 0.50 \\
Specific Gravity at $15 / 15^{\circ} \mathrm{C}$ & 0.8966 \\
Dry Specific Gravity at $15 / 15^{\circ} \mathrm{C}$ & 0.8961 \\
API Gravity at $15 / 15^{\circ} \mathrm{C}$ & 26.4 \\
Kinematic Viscosity at & 10.5 \\
$400^{\circ} \mathrm{C}$ (cst) & \\
\hline
\end{tabular}

Table 2 Detected Selected PAHs in the sampled crude oil according to the calibrated standard

\begin{tabular}{|c|c|c|c|c|c|c|}
\hline Compounds & $\begin{array}{l}\text { Retention } \\
\text { Time } \\
\text { (min) }\end{array}$ & $\begin{array}{l}\text { Molecular } \\
\text { Formula }\end{array}$ & $\begin{array}{l}\text { Nominal } \\
\text { Molecular } \\
\text { Mass }(\mathrm{m} / 2)\end{array}$ & $\begin{array}{l}\text { Mass } \\
\text { Concentration } \\
\left(\mathrm{mg} / \mathrm{cm}^{3}\right)\end{array}$ & $\begin{array}{l}\text { Mass } \\
\text { Concentration } \\
(\mathrm{mg} / \mathrm{l})\end{array}$ & $\begin{array}{l}\text { Responses } \\
\text { Values }\end{array}$ \\
\hline Eluorene & 10.666 & $\mathrm{C} 13 \mathrm{HlO}$ & 166 & 2.2 & 0.044 & 2240 \\
\hline Phenanthrene & 12.159 & $\mathrm{C} 14 \mathrm{HlO}$ & 178 & 17.93 & 0.359 & 36734 \\
\hline Anthracene & 12.159 & $\mathrm{C} 14 \mathrm{Hl} 0$ & 178 & 14.09 & 0.282 & 36734 \\
\hline Elouranthene & 14.786 & $\mathrm{Cl} 6 \mathrm{HlO}$ & 202 & 20.64 & 0.413 & 280 \\
\hline Pxxene & 15.362 & $\mathrm{C} 16 \mathrm{HlO}$ & 202 & 21.90 & 0.438 & 182 \\
\hline Benz(e)acephenanthrylene & 23.706 & $\mathrm{C} 22 \mathrm{H} 12$ & 252 & 56.98 & 1.140 & 161 \\
\hline $\begin{array}{l}\text { Benzo(e)pyxene } \\
\text { Total PAHS }\end{array}$ & 24.948 & $\mathrm{C}_{2} 2 \mathrm{H} 12$ & 252 & $\begin{array}{l}55.58 \\
189.32 \\
\end{array}$ & $\begin{array}{l}1.112 \\
3.788 \\
\end{array}$ & 133 \\
\hline
\end{tabular}

Mass Concentration in $\mathrm{mg} / \mathrm{l}=$ Mass Concentration (mg/cm3) x (2/100); Amount of sample injected into the GC-MS instrument $=2$; Amount of sample extracted $=100$ 
Table 3 Comparison of Selected PAHs in Crude oil and Simulated Petroleum Wastewater at Daily Interval for 4day

\begin{tabular}{llllll}
\hline Compounds & $\begin{array}{l}\text { Initial Mass } \\
\text { Concentration } \\
(\mathrm{mg} / \mathrm{l})\end{array}$ & Mass Concentrations of PAHS (mg/l) \\
& 0.044 & Day l & Day 2 & Day 3 & Day 4 \\
Eluorene & 0.126 & 0.067 & 0.192 & 0.107 \\
Phenanthrene & 0.359 & 0.401 & 0.356 & 0.384 & 0.387 \\
Anthracene & 0.282 & 0.326 & 0.279 & 0.308 & 0.311 \\
Benz(e)acephenanthrylene & 1.140 & 1.163 & 1.140 & 1.141 & 1.151 \\
Benzo(e)pyxene & 1.112 & 1.112 & 1.112 & 1.112 & 1.112 \\
Total PAHS & 2.940 & 3.128 & 2.954 & 3.137 & 3.068 \\
\hline
\end{tabular}

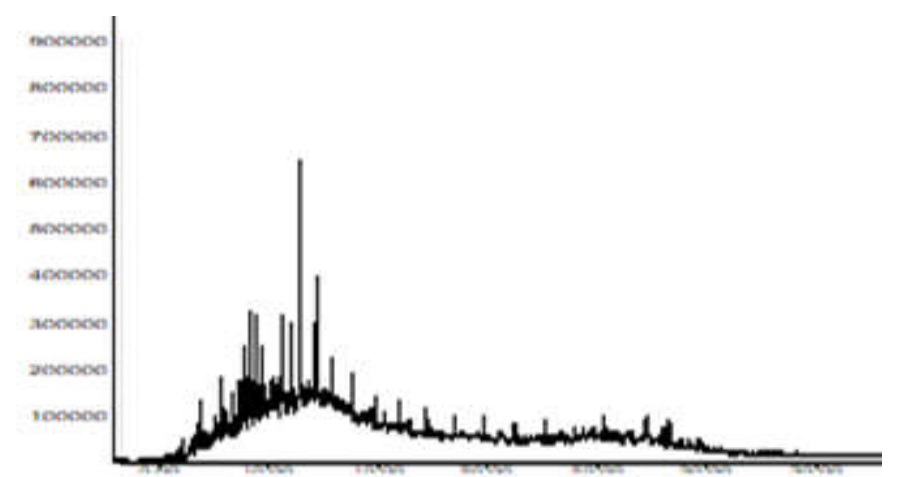

Fig 1: Spectra of Simulated Petroleum wastewater indicating PAHs, Frist day sampling.

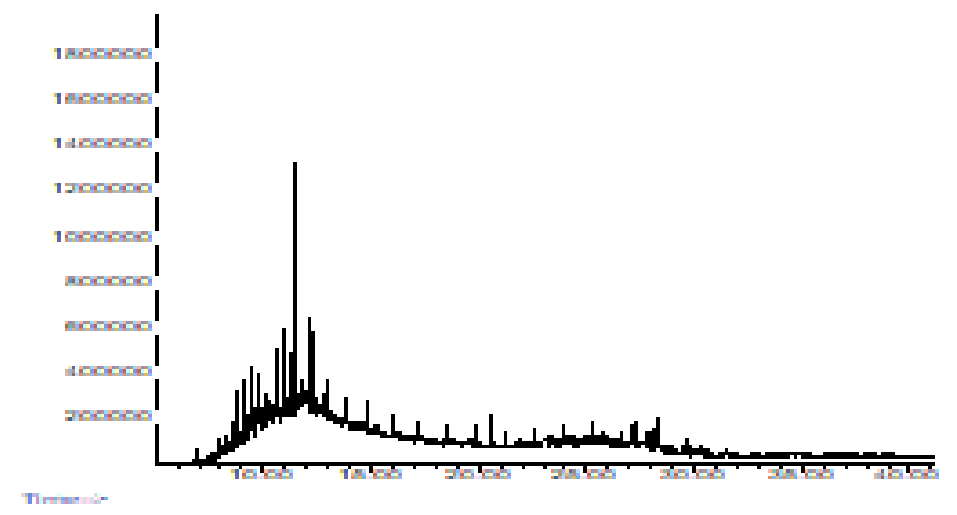

Fig 2: Spectra of Simulated Petroleum wastewater indicating PAHs, Second day sampling.

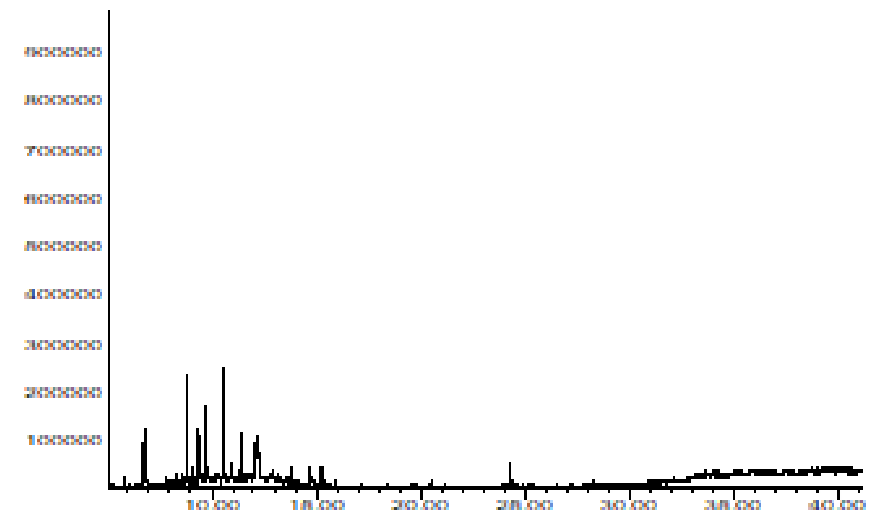

Fig 3: Spectra of Simulated Petroleum wastewater indicating PAHs, Third day sampling.
The parameters in Table 1 are important in classification of crude oil samples. According to API, (2011), crude oil sample with API gravity greater than 31 are classified as light crude oil, those between 2231 are medium crude, while those of 20 and below are referred to as heavy crude oil. The API gravity of crude oil increases as specific gravity decreases. API (2011) further stated that crude oils with lower densities and viscosities, and thus higher API gravities, usually contain higher levels of naphtha (gasoline-range hydrocarbons) with predominately volatile paraffinic hydrocarbons, which can be processed readily to produce gasoline and are considered "light" crude. Heavy crude oils are more viscous, have higher boiling ranges and higher densities, and thus have lower API gravities. Heavy crude oils are usually rich in aromatics and tend to contain more residual material, e.g. asphaltenes, and heterocyclics, which includes sulfur, nitrogen, oxygen-containing hydrocarbon analogs. This then expresses the fact that light or medium crude oil may contain minor to trace amount of larger polynuclear aromatic hydrocarbons (PAHs) and sulfur containing compounds as seen in Tables 2 and 3.This result are consistent with Walters, (2007) findings. Table 2 reveals that the PAHs in the crude oil sample that was simulated as petroleum wastewater, are Fluorene (FL), phenanthrene (Phe), anthracenes(Ant), benzo (e) acephenanthylene $(\mathrm{BeA})$, benzo (e) pyrene $(\mathrm{BeP})$, according to the standard used in calibrating. In Table 3, the mass concentration of Fluorene, phenanthrene, anthracenes, benzo acephenanthylene, benzo (e) pyrene, are ranging from 0.044 to $1.5856 \mathrm{mg} / 1$ thus buttressing the classification of the crude as medium light due to trace amount of PAHs. 


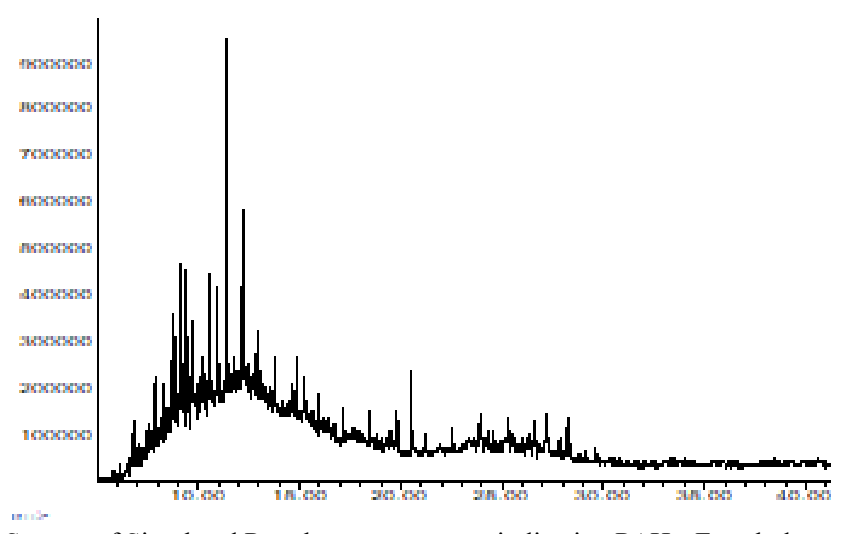

Fig 4: Spectra of Simulated Petroleum wastewater indicating PAHs, Fourth day

The total PAHs in simulated wastewater does not show a clear trend, contrary to the expectation that there should be a progressive increase with time due to photolysis or photodecomposition of compounds or PAHs (Table 3). Day 2 shows a drop in total concentration of PAHs when compared to day one. Similarly, day 4 shows a drop in total concentration of PAHs when compared to day 3. This may have been due to many factors such as extraction processes, preservation methods and analytical procedures on GC-MS. Fig 1-4 shows Spectra of Simulated Petroleum wastewater indicating selected PAHs, during the four days of sampling.

Effectiveness of tested activated carbon in removal of selected PAHs from petroleum contaminated water: The rate at which selected PAHs were removed from petroleum contaminated water at daily interval for a period of 5hrs is shown in Tables 4-7.
It was observed that some of the selected PAHs were not detected after remediation while some were detected after remediation. It may be inferred that $\mathrm{COA} \mathrm{KCl}$ and $\mathrm{CBV}$ $\mathrm{H}_{3} \mathrm{PO}_{4}$ were effective in removal of those PAHs that are not detected after remediation. It may also be as a result of lower resolution factors of the GC-MS employed in the analysis. The percentage removal efficiency for each selected PAHs analyzed was observed to be low. Table 4 revealed a range of 6.2 $14.6 \%$ removal efficiency of each selected PAH with a total percentage efficiency of $27.7 \%$ for $\mathrm{COA} \mathrm{KCl}$. CBV $\mathrm{H}_{3} \mathrm{PO}_{4}$ produced $10.26-15.20 \%$ removal efficiency for each selected PAH with a total percentage efficiency of 50.8. Total percentage efficiency for each tested carbon used for remediation increased on the 2nd day with $41.3 \%$ for $\mathrm{COA} \mathrm{KCl}$ and $63.4 \%$ for $\mathrm{CBV} \mathrm{H} \mathrm{PO}_{4}$.

Table 4 Quantity of PAHs removed tested activated carbon $\left(\mathrm{COA} \mathrm{KCl}\right.$ and $\mathrm{CBV} \mathrm{H}_{3} \mathrm{PO}_{4}$ ) at 5 hrs Contact time and $1^{\text {st }}$ day sampling.

\begin{tabular}{llllll}
\hline & $\begin{array}{l}\text { Initial Mass } \\
\text { Concentratio } \\
\text { ns of PAHS } \\
(\mathrm{mg} / \mathrm{l}) \text { Dayl }\end{array}$ & $\begin{array}{l}\text { Final concentrations } \\
\text { of PAHS adsorbed } \\
\text { by COA }(\mathrm{KCl})\end{array}$ & $\begin{array}{l}\text { Percentage } \\
\text { Removal } \\
\text { Efficiency } \\
\mathrm{COA}(\mathrm{KCl}) \%\end{array}$ & $\begin{array}{l}\text { Final concentrations } \\
\text { of PAHS adsorbed } \\
\text { by CBV }\left(\mathrm{H}_{3} \mathrm{PO}_{4}\right)\end{array}$ & $\begin{array}{l}\text { Percentage } \\
\text { Removal }\end{array}$ \\
$\begin{array}{l}\text { Efficiency CBV } \\
\left(\mathrm{H}_{3} \mathrm{PO}_{4}\right) \%\end{array}$ \\
\hline $\begin{array}{l}\text { Fluorene } \\
\text { Phenanthrene }\end{array}$ & 0.126 & 0.114 & 10.02 & $\mathrm{ND}$ & 14.11 \\
$\begin{array}{l}\text { Anthracene } \\
\text { Benz(e)acephenant }\end{array}$ & 0.401 & 0.349 & 13.11 & 0.345 & 15.20 \\
$\begin{array}{l}\text { hrylene } \\
\text { Benzo(e)pyrene }\end{array}$ & 0.325 & 0.278 & 14.61 & 0.276 & 14.30 \\
Total PAHS & 1.163 & 1.091 & 6.2 & 0.996 & 10.27 \\
\hline
\end{tabular}

ND: Not detected, $\mathrm{COA} \mathrm{KCl:} \mathrm{Oxytenanthera} \mathrm{abyssinaca} \mathrm{activated} \mathrm{with} \mathrm{KCl} ; \mathrm{CBV}_{3} \mathrm{PO}_{4}$ : Bambusa vulgaris activated with $\mathrm{H}_{3} \mathrm{PO}$

Table 5 Quantity of PAHs removed tested activated carbon $\left(\mathrm{COA} \mathrm{KCl}\right.$, and $\left.\mathrm{CBV} \mathrm{H}_{3} \mathrm{PO}_{4}\right)$ at 5 hrs Contact time and $2^{\text {nd }}$ day sampling.

\begin{tabular}{|c|c|c|c|c|c|}
\hline Compounds & $\begin{array}{l}\text { Initial Mass } \\
\text { Concentration } \\
5 \text { of PAHS } \\
(\mathrm{mg} / \mathrm{l}) \mathrm{Day} 2\end{array}$ & $\begin{array}{l}\text { Final concentrations } \\
\text { of PAHS adsorbed } \\
\text { by } \mathrm{COA}(\mathrm{KSl}) \mathrm{mg} / 1\end{array}$ & $\begin{array}{l}\text { Percentage } \\
\text { Removal } \\
\text { Efficiency } \\
\text { COA (KCl) \% }\end{array}$ & $\begin{array}{l}\text { Final concentrations } \\
\text { of } \mathrm{PAHS} \text { adsorbed } \\
\text { by } \mathrm{CBV}\left(\mathrm{H}_{3} \mathrm{PO}_{4}\right. \\
\text { )mg/ }\end{array}$ & $\begin{array}{l}\text { Percentage } \\
\text { Removal } \\
\text { Efficiency CBV } \\
\left(\mathrm{H}_{3} \mathrm{PO}_{4}\right) \%\end{array}$ \\
\hline Eluorene & 0.067 & ND & & $\mathrm{ND}$ & \\
\hline Phenanthrene & 0.356 & 0.293 & 17.58 & 0.293 & 17.7 \\
\hline Anthracene & 0.280 & 0.227 & 19.31 & 0.226 & 9.3 \\
\hline $\begin{array}{l}\text { Benz(e)acephenanthr. } \\
\text { vlene. }\end{array}$ & 1.14 & 1.023 & 10.23 & 1.024 & 10.2 \\
\hline Benzo (e)pyxene & 1.112 & 0.999 & 10.12 & ND & \\
\hline Total PAHS & 2.955 & 2.542 & 41.3 & 1.759 & 63.4 \\
\hline
\end{tabular}

ND: Not detected, $\mathrm{COA} \mathrm{KCl:} \mathrm{Oxytenanthera} \mathrm{abyssinaca} \mathrm{activated} \mathrm{with} \mathrm{KCl} ; \mathrm{CBV}_{3} \mathrm{PO}_{4}$ : Bambusa vulgaris activated with $\mathrm{H}_{3} \mathrm{PO}{ }_{4}$. 
Table 6 Quantity of PAHs removed tested activated carbon $\left(\mathrm{COA} \mathrm{KCl}\right.$ and $\left.\mathrm{CBV} \mathrm{H}_{3} \mathrm{PO}_{4}\right)$ at 5 hrs Contact time and $3^{\text {rd }}$ day sampling.

\begin{tabular}{llllll}
\hline Compounds & $\begin{array}{l}\text { Initial Mass } \\
\text { Concentrations of } \\
\text { PAHS (mg/) } \\
\text { Day3 } 3\end{array}$ & $\begin{array}{l}\text { Final concentrations } \\
\text { of PAHS adsorbed } \\
\text { by COA (KCl)mg/1 }\end{array}$ & $\begin{array}{l}\text { Percentage } \\
\text { Removal } \\
\text { Efficiency } \\
\text { COA (KCl) } \%\end{array}$ & $\begin{array}{l}\text { Final concentrations } \\
\text { of PAHS adsorbed } \\
\text { by CBV }\left(\mathrm{H}_{3} \mathrm{PO}_{4}\right. \\
\text { )mg/1 }\end{array}$ & $\begin{array}{l}\text { Percentage } \\
\text { Removal } \\
\text { Efficiency CVB } \\
\left(\mathrm{H}_{3} \mathrm{PO}_{4}\right) \%\end{array}$ \\
\hline $\begin{array}{l}\text { Eluorene } \\
\text { Phenanthrene }\end{array}$ & 0.192 & $\mathrm{ND}$ & 100 & $\mathrm{ND}$ & 100 \\
Anthracene & 0.384 & $\mathrm{ND}$ & 100 & $\mathrm{ND}$ & 100 \\
$\begin{array}{l}\text { Benz(e)acephenantbr. } \\
\text { ylens }\end{array}$ & 0.308 & $\mathrm{ND}$ & 100 & $\mathrm{ND}$ & 100 \\
Benzo(e)pyxene & 1.141 & 1.024 & 10.25 & $\mathrm{ND}$ & 100 \\
Total PAHS & 1.112 & $\mathrm{ND}$ & 100 & $\mathrm{ND}$ & 100 \\
\hline
\end{tabular}

ND: Not detected, COA KCl: Oxytenanthera abyssinaca activated with KCl; CBV H3PO4: Bambusa vulgaris activated with H3PO4.

\begin{tabular}{|c|c|c|c|c|c|}
\hline Compounds & $\begin{array}{l}\text { Initial Mass } \\
\text { Concentratio } \\
\text { ns of PAHS } \\
(\mathrm{mg} / \mathrm{l}) \text { Day } 4\end{array}$ & $\begin{array}{l}\text { Final concentrations } \\
\text { of PAHS adsorbed } \\
\text { by } \mathrm{COA}(\mathrm{KC}) \mathrm{mg} / \mathrm{l}\end{array}$ & $\begin{array}{l}\text { Percentage } \\
\text { Removal } \\
\text { Efficiency } \\
\text { COA (KCl) \% }\end{array}$ & $\begin{array}{l}\text { Final concentrations } \\
\text { of PAHS adsorbed } \\
\text { by } \mathrm{CBV}\left(\mathrm{H}_{3} \mathrm{PO}_{4}\right) \\
\mathrm{mg} / 1\end{array}$ & $\begin{array}{l}\text { Percentage } \\
\text { Removal } \\
\text { Efficiency CBV } \\
\left(\mathrm{H}_{3} \mathrm{PO}_{4}\right) \%\end{array}$ \\
\hline Eluorene & 0.107 & $\mathrm{ND}$ & 100 & $\mathrm{ND}$ & 100 \\
\hline Phenanthrene & 0.387 & ND & 100 & $\mathrm{ND}$ & 100 \\
\hline Anthracene. & 0.311 & $\mathrm{ND}$ & 100 & $\mathrm{ND}$ & 100 \\
\hline $\begin{array}{l}\text { Benz (e)acephenzatbr. } \\
\text { vlene }\end{array}$ & 1.151 & 0.895 & 22.28 & $\mathrm{ND}$ & 100 \\
\hline $\begin{array}{l}\text { Benzo(e)pyxene } \\
\text { Total PAHS }\end{array}$ & $\begin{array}{l}1.112 \\
3.068\end{array}$ & $\begin{array}{l}\mathrm{ND} \\
0.895\end{array}$ & $\begin{array}{l}100 \\
70.8\end{array}$ & $\begin{array}{l}\mathrm{ND} \\
\mathrm{ND}\end{array}$ & $\begin{array}{l}100 \\
100\end{array}$ \\
\hline
\end{tabular}

ND: Not detected, COA KCl: Oxytenanthera abyssinaca activated with $\mathrm{KCl}$; $\mathrm{CBV} \mathrm{H3PO4:} \mathrm{Bambusa} \mathrm{vulgaris} \mathrm{activated} \mathrm{with} \mathrm{H} 3 \mathrm{PO} 4$.

For each PAH selected, the removal efficiency remained at a range of $10.11-19.3 \%$ for $\mathrm{COA} \mathrm{KCl}$ and $10.15-19.3 \%$ for $\mathrm{CBV} \mathrm{H}_{3} \mathrm{PO}_{4}$ (Table 5). There were further increases in Table 6 with an appreciable removal percentage of $67.5 \%$ for $\mathrm{COA} \mathrm{KCl}$, while there was no detection of parameters with $\mathrm{CBV} \mathrm{H}_{3} \mathrm{PO}_{4}$ adsorbent. Table 7 shows that reduction in total PAHs has little difference when compared to day 3 , for COA $\mathrm{KCl}$ and no detection for $\mathrm{CBA} \mathrm{H}_{3} \mathrm{PO}_{4}$. Comparing the efficiency of tested adsorbent used for remediation of different concentration of PAHs per day for duration of 4 days, it can be inferred that $\mathrm{CBV} \mathrm{H}_{3} \mathrm{PO}_{4}$ showed greater removal efficiency with percentage range of 50.8-100, while $\mathrm{COA} \mathrm{KCl}$ showed a lower removal efficiency of $27.7-70.8 \%$.

These may have resulted from chemical interaction between the adsorbent and adsorbate due to their surface contact. The acid activated adsorbent (CBA $\left.\mathrm{H}_{3} \mathrm{PO}_{4}\right)$ is negatively charged while $\mathrm{COA} \mathrm{KCl}$ is positively charged. It can then be deduced that an adsorbent with positively charged surface will attract anions while those of negatively charged will attract cations. This indicates that selected PAHs in petroleum contaminated water are positively charged and are easily attracted to negatively charged adsorbent

Conclusion: This study shows that adsorbens made from Bambusa vulgaris and Oxytenanthera abyssinaca and activated with Phosphoric acid $\left(\mathrm{H}_{3} \mathrm{PO}_{4}\right)$ and Potassium chloride $(\mathrm{KCl})$ as dehydrating agent respectively, efficiently adsorbed selected PAHs in petroleum wastewater, hence are good adsorbents that can be adopted in the petroleum industries for remediation operations. Since PAHs in contaminated water increases with time due to photodecomposition thus early treatment should be considered when there are spillages on waterways.

Acknowledgement: The authors are grateful to the following organizations in Nigeria that afforded them the opportunity to use their facilities and contributed to this study; National Petroleum Investment Management Services (NAPIMS): Department of Health, Safety, Security and Environment (HSSED), Chevron Nigeria Limited, Health, Safety and Environment unit (HSE), The Shell Petroleum Development Company of Nigeria Limited, Remediation Unit. Members of Analytical unit of Central Research Laboratory, University of Lagos, Akoka, Nigeria

\section{REFERENCES}

Aroh, KN. Ubong, IU. Eze, CL. Harry, IM. UmoOtong, JC. Gobo, AE. 2010. Oil spill incidents and pipeline vandalization in Nigeria - Impact on public health and negation to attainment of Millennium development goal: the Ishiagu example. Disaster Prevention and Management, 19 (1):70-87.

Ayotamuno, M.J. Akor, A.J. Igho, T J. 2002. Effluent quality and wastes from petroleum drilling 
operations in the Niger Delta, Nigeria. Environmental Management and Health, 13(2):207-216.

Ekundayo, EO. Obuekwe, CO. 1997. Effects of an oil spill on soil physico-chemical properties of a spill site in a typic Paleudult of Midwestern Nigeria. Environmental Monitoring and Assessment, 45: 209-221.

Haritash, AK. Kaushik, CP. 2009. Characterization of synthetic carbon activated with phosphoric acid. Applied surface J. Hazard. Mater. 1(16): 1-5

Isehunwa, SO. Onovae, S. 2011. Evaluation of produced water discharge in Niger-Delta. ARPN Journal of Engineering and Applied Science. 6(8): 66-72.

Jeffrey, L. 2010. Towards a Novel Methodology for Environmental Remediation of Oil-polluted Aqueous Systems. A Ph.D. Thesis, University of Aberdeen, Aberdeen, United Kingdom.

John, AV. Markus, GP. Deborah, E. Robert, JR. 2004. A White Paper Describing Production of Crude oil, Natural gas and Coal Bed Methane. U.S. Department of Energy, National Energy Technology Laboratory, prepared under contact W-31-109-Eng 38.

Kadafa, A.A. 2012. Oil exploration and spillage in the Niger Delta of Nigeria. Civil and Environmental Research, 2 (3): 38-51.

Lindholm-Lehto, CP. Ahkola, H; Knuutinen, SJ. 2016. Procedures of determining organic trace compounds in municipal sewage sludge-a review. Environ. Sci. Pollute. Res. 24 (10): 64736499.
Meijer, DT; Madin, C. 2010. Removal of dissolved and dispersed hydrocarbons from oil and gas produced water with mppe technology to reduce toxicity and allow water reuse. APPEA Journal. 50:1-11.

Noelia, RG. 2011. Organic contaminants in environmental atmospheres and waters. Doctoral thesis. Departament de Química Analítica i Química Orgànica. Universitat RoviraI VIRGILI. Pp 1-399.

Pampanin, DM. Sydnes, MO. 2013. Polycyclic Aromatic Hydrocarbons a Constituent of Petroleum: Presence and Influence in the Aquatic Environment. Chapter 5, 83-118.

Sangodoyin, AY, 1993. Consideration on contamination of groundwater by waste disposal systems in Nigeria. Environ. Technol. 14: 957-964

UNITED STATES ENVIRONMENTAL PROTECTION AGENCY (USEPA). 1999. National recommended water quality criteria-Correction: EPA 822/Z-99001, USEPA Washington DC.

WHO.1998.Polycyclic aromatic hydrocarbons, selected non eterocyclic. Environmental HealthCriteria 202.

Walters, C. (2007). The Origin of Petroleum: Practical Advances in Petroleum Processing. Pp 76-101

Zubaidy, EA. 2012. Effect of Activated of Date Palm Kernel Powder on the Remediation Process of oil polluted water. Inter. J. Environ. Pollute. Remediate. 1 (1):38-43. 